\title{
IGLL1 wt Allele
}

National Cancer Institute

\section{Source}

National Cancer Institute. IGLL1 wt Allele. NCI Thesaurus. Code C118231.

Human IGLL1 wild-type allele is located in the vicinity of 22 q11.23 and is approximately 7 $\mathrm{kb}$ in length. This allele, which encodes immunoglobulin lambda-like polypeptide 1 protein, is involved in the development and function of B-cells. Mutation of the gene is associated with agammaglobulinemia 2 . 